\title{
Clusterin: always protecting. Synthesis, function and potential issues.
}

\author{
Carmen Rodriguez-Rivera ${ }^{1}$, Miguel Martínez García ${ }^{1}$, Miguel Molina-Álvarez ${ }^{2}$, Carmen \\ González-Martín ${ }^{3}$, and Carlos Goicoechea ${ }^{2}$ \\ ${ }^{1}$ Rey Juan Carlos University \\ ${ }^{2}$ Universidad Rey Juan Carlos \\ ${ }^{3}$ Universidad CEU San Pablo
}

October 9, 2020

\begin{abstract}
In the last years, clusterin, a challenging and paradoxical apolipoprotein, has been of growing interest amongst a rising number of scientists. This enigmatic protein is present in all fluids of the organism besides within the intracellular matrix, and it plays diverse, and at times contrary, roles in a growing number of pathologies. It seems to vary its location and function to assure cellular survival being cytoprotective hence its significance in neuroprotection and cancer along with chemotherapy resistance. However, it can also lead to cellular arrest and its modulation to apoptosis. Additionally, it has been described to modulate pain, as well as linked to inflammation, cardioprotection, satiety and hunger, and possibly to addictive behaviour development .Thus, it has been postulated to be used both as a biomarker and a very explorable new therapeutic target for several conditions.
\end{abstract}

\section{Hosted file}

Clusterin always protecting.pdf available at https://authorea.com/users/365906/articles/ 485829-clusterin-always-protecting-synthesis-function-and-potential-issues

\section{Hosted file}

Figure 1.pdf available at https://authorea.com/users/365906/articles/485829-clusterin-alwaysprotecting-synthesis-function-and-potential-issues

\section{Hosted file}

figure 2.pdf available at https://authorea.com/users/365906/articles/485829-clusterin-alwaysprotecting-synthesis-function-and-potential-issues

\section{Hosted file}

Figure 3.pdf available at https://authorea.com/users/365906/articles/485829-clusterin-alwaysprotecting-synthesis-function-and-potential-issues

\section{Hosted file}

Table 1.pdf available at https://authorea.com/users/365906/articles/485829-clusterin-alwaysprotecting-synthesis-function-and-potential-issues 